\title{
Evaluating the Role of the Marketing Managers in the Management Process of Marketing: The Case of the Textile Industry in Jordan
}

\author{
HUSSEIN ABDULlAH EL-OMARI \\ Assistant Professor \\ Department of Business Administration \& Accounting, \\ The Hashemite University, Al-Zarqa, Jordan
}

( Received 27.8.1418H, and Accepted 16.6.1419H )

\begin{abstract}
Studies on marketing managers in Jordan are rare, therefore, this study is considered of great importance. It examines, quantitatively, the role of the marketing manager in the functions of the marketing management process in the context of the textile industry in Jordan.

A sample of 220 Jordanian textile manufacturers was selected at random, using a simple random sampling procedure, from the population of study (i.e., 309 Manufacturers). Questionnaires were hand-delivered to their marketing managers. This procedure resulted in a return of 168 questionnaires representing 168 textile manufacturers. Of the returned questionnaires, 161 were usable and the other seven questionnaires were incomplete and, therefore, were neglected.

The findings of this study have indicated that those managers have a very weak role to play in analyzing, planning, organizing, implementing and controlling their firms' marketing activities. This will result in a negative impact on the manufacturer's competitiveness locally and internationally. Therefore, marketing managers of those manufactrers must be given their real roles in the marketing management process.
\end{abstract}

\section{Introduction}

The relationship between marketing and the success of any business organization must be acknowledged by every employee regardless of his/her managerial level. Recruiting and employing the right marketing manager is as important as the importance of the soul to the body. Marketing managers have an important role to play in facilitating the coordination of all firm's activities and in ensuring effective and smooth flow of interaction. Good marketing managers are also cost-conscious and, in that, they help in managing large portions of their firms resources. A big percentage of these resources are spent in the area of marketing (Kotler and Armstrong, 1994). 
Therefore, successful marketing managers are key executives in formulating the overall business strategy. They should have as much authority and as nearly as possible be held for the success of their marketing strategies. Strategic planning is defined by Peter and Donnely, (1991, p.8) as:

"The process of developing and maintaining all of the activities that lead to the development of a clear organizational mission, organizational objectives, and appropriate strategies to achieve the objectives for the entire organization".

Many of today's most successful firms are here today because many years ago they offered the right product at the right time to rapidly growing markets. Many of the critical decisions of the past were made without the benefit of strategic planning. Whether wisdom or just luck were the main bases for their decisions is not important. They resulted in a momentum which has carried these firms to where they are today. However, with the large increase in the level of competition, firms are realizing the importance of marketing management and increasingly recognizing that wisdom and intuition alone are no longer sufficient to guide the future of their large organizations in today's ever-changing environments (George, S., 1994). Marketing management relies heavily on designing the firm's offering in terms of the needs and desires of the target market and on using effective pricing, communication, and distribution to inform, motivate and service the market (Kotler, P., 1994).

So, who is a marketing manager? And what does he do ?

A marketing manager is responsible for the process of planning, organizing, implementing and controlling marketing activities to facilitate and expedite changes effectively and efficiently (Pride and Ferrel, 1989, pp. 644,646).

It is evident from the definition that the purpose of a marketing manager is to facilitate highly desirable exchanges and to minimize as much as possible the costs of doing so through the proper use of the four main management functions. Studies of this type in the Jordanian context are rare and, hence, the main aim of this study is to examine whether or not marketing managers play an important role in the functions of the marketing management process of their textile manufacturers in Jordan.

\section{Marketing Planning}

Marketing planning is always seen as a systematic process that involves assessing marketing opportunities and resources, determining marketing objectives, and developing a plan for implementation and control (Ferrel, George and David, 1994).

Managing the marketing function starts with a thorough analysis of the company's situation. To find attractive opportunities and avoid environmental threats, marketing managers must analyze their marketing environments. These analyses should help in deciding which opportunity can be successfully pursued. In addition, these analyses feed valuable information to each function of the marketing management (Ravi, A., 1991).

Once a marketing opportunity is defined, the marketing manager must then plan an appropriate strategy for taking advantage of it. This process can be summarized in 
three interrelated tasks: (a) establishing marketing objectives; (b) selecting the target market; and (c) developing the marketing mix (Guiltinan and Paul, 1991).

\section{a. Establishing marketing objectives}

Almost all firms measure the success of their marketing managers based on the achieved results, which should reflect the objectives of the marketing strategy. Marketing managers must have clear and realistic objectives to achieve the following:

- Determining what needs to be accomplished.

- Motivating the staff to achieve what needs to accomplished.

- Providing a timetable for implementing the marketing plan.

- Measuring marketing performance, i.e., whether or not goals are being reached.

\section{b. Selecting the target market}

Marketing managers should identify and select their target market(s) before deciding on specific strategies in the marketing area. If they know who their likely customers are, marketing managers will be in a much better position to provide the desired products and services to their market segments. In addition, promotion, pricing and distribution strategies can be tailored to segment needs (Weinstein, A., 1987).

\section{c. Developing the marketing mix}

Marketing managers are responsible for developing the marketing mix which is the set of controllable variables that must be managed to satisfy the target market and achieve organizational objectives. These controllable variables are usually classified according to four major decision areas: Product, Price, Place and Promotion (De Bruiker and Summe, 1985).

Marketing managers realize that, maximizing the effectiveness of these variables should be broadly based on segmentation findings, as well as other strategic variables (e.g., company resources, management's values and policies, potential risk and return, etc.). Unlike the external environment, firms have complete control over the marketing methods they employ to meet their objectives (Ajay and Bernard, 1990). Those managers should understand that the marketing mix is the core of the marketing management process.

\section{Organizing Marketing Activities}

Good organization of a marketing unit is important for a firm's marketing management to effectively plan and implement its marketing strategies. Establishing authority and responsibility relationships between members of the marketing department depends largely on the organizational structure of a marketing department. Dividing the work into different activities and delegating responsibilities and authorities to the concerned person(s) in different positions of the marketing department, is a strategy usually used by marketing managers to organize a marketing unit. Delegation of responsibilities and authorities may be given to the sales manager, advertising manager and $\mathrm{R} \& \mathrm{D}$ manager.

Different businesses require different methods of organizing for marketing activities. No single method could be used in all firms. However, a marketing manager 
can organize a marketing unit according to: (a) functions (b) products(c) regions, and (d) types of customers characteristics of the identified target market(s) (Robert, W., 1986). Number and nature of the firm's products, the business environment as a whole and other factors are also determining factors in what method(s) need to be used in organizing a marketing unit.

The use of a combination of these methods is the common practice of marketing managers in today's world of business. This practice allows marketing managers to establish a more flexible marketing unit which, in turn, would help in developing and implementing better marketing plans to match customers' needs precisely. Whatever is the method, marketing managers recognize the importance of good organization in giving their firms competitive advantages over their competitors (Robert, J., 1995).

\section{Implementing and Controlling the Marketing Activities}

Implementing the marketing activities means executing the marketing plan and creating exchanges. A plan is nothing unless it degenerates into work. Not all marketing plans which are developed with great care can be executed with perfect timing (Cook, V., 1983). Therefore, the marketing manager must monitor and coordinate the execution of the marketing plan. Because of changes in the company's micro and macro environments, marketing managers may need to modify or adjust their plans. Moreover, marketing managers need to motivate their personnel to execute the marketing plan more efficiently.

To achieve marketing goals and organizational objectives, marketing managers must control marketing efforts. Controlling the execution of a marketing plan involves three basic steps (Aaker, D. 1988). First, measuring the results of the executed marketing plan. Second, comparing these results with the objectives that are stated in the marketing plan. Third, if the plan is not achieving the objectives, modifications and adjustments are necessary if the firm wishes to achieve the planned objectives. Furthermore, marketing managers should remember the importance of having good Marketing Management Information Systems (MMIS) in planning or modifying their marketing plans (Yoram and Robertson, 1983). Effective marketing decisions are usually made through the use of current, reliable and valid information which could be obtained from their Marketing Management Information Systems.

The job of a marketing manager is huge and demanding. A good marketing manager is not a charming salesman, as most people think, but rather a manager who knows well the art and the science of marketing, and who makes things happen as planned, if not better.

\section{Objective of the Study}

The main objective of this study is to examine whether or not marketing managers in Jordan play an important role in the functions of the marketing management process. In other words, whether those managers have an important role to play in analyzing, planning, organizing, implementing and controlling their companies' marketing activities. 


\section{Study Hypothesis}

Based on the extensive literature review, the following hypothesis was formulated to be tested in this study.

$\mathrm{H} 1$ "Marketing managers have a secondary role to play in the marketing management process of their textile manufacturers in Jordan".

\section{Methodology}

This section covers two main issues, i.e., questionnaire development and data collection.

\subsection{Questionnaire Development}

The main concern in this study was the development of constructs. In developing constructs, there are no hard and fast rules. Fortunately, the literature has some good guidelines that help researchers and writers to avoid the most common mistakes such as, complexity and ambiguity, and to be as specific and accurate as possible.

All constructs used in this study were either used in previous research or operationalised being guided by their definitions in the literature (e.g., King, 1985; Weinstein, 1987; Pride and Ferrel, 1989; Dick, 1993; Kostecki 1994, Peter and Donnelly, 1995; Bearden, Ingram and Lafroge, 1995). Ensuring content validity of all constructs used in the current study was the reason for depending heavily on the literature. No single previous study used all the constructs of the current research and, therefore, the researcher had to collect the constructs from many previous studies.

To be used in the field study of the current research, the completed English version of the questionnaire was translated, by the researcher, into Arabic. For using an accurate terminology, the researcher received some help from an Arabic language specialist.

The Arabic version of the questionnaire was subject to a pilot test study on a small sample of 50 textile manufacturers drawn (using a systematic sampling procedure) from the original sample (i.e., 220 manufacturers selected based on a simple random sampling procedure). The obtained responses, of the pilot study, gave a clear picture to the researcher. Therefore, some questions had to be amended or excluded and others had to be added.

To increase reliability and to minimize measurements' errors, each function of the marketing management process was measured by using more than one question. In addition, reliability analysis was also carried out and the results were encouraging (Alpha values were $>0.65$ suggested by Nunnally, 1978).

\subsection{Data collection}

The textile industry in Jordan was the setting for the empirical study. According to Jordan's latest Statistical Yearbook No. 46 of October 1996, the number of textile manufactures (the population of Study) in Jordan is 309 (i.e., Small, medium and large size manufacturers). The names and addresses of them were obtained from the Chamber of Industry. 220 manufacturers (i.e., $71.2 \%$ of the population of study) were 
selected at random, using asimple random sampling procedure. The reason for selecting 220 manufacturer is related to the following factors:

1- Selecting two thirds (i.e., $71.2 \%$ ) of the total population of study would allow all sizes of textile manufacturers (i.e., small, medium and large size manufacturers) to be represented in the sample.

2- Of 309 textile manufacturer 153 are classified as small manufacturers, thus, a sample size had to be determined and a simple random procedure had to be used to give equal chances for all sizes of textile manufacturers to be represented in the sample. Therefore, the selected sample size included the following :

$$
\begin{aligned}
& \text { a- } \text { Small size textile manufacturers }=93 \\
& \text { b- Medium size textile manufacturers }=71 \\
& \text { c- Large size textile manufacturers }=56
\end{aligned}
$$

Total 220

3- The selected sample size (i.e., 220 manufacturer) represented two-third of the total population of study. It was thought that this sample size is adequate for this type of study. This was reached after extensive consultation with experts from both the academic field and the Jordanian Chamber of Industry.

After that, 220 questionnaires were hand-delivered to marketing managers working with those selected. 168 questionnaires were returned and of that, 161 questionnaires were usable for analysis. The response rate, usable questionnaires, was $73.2 \%$, however, a follow-up study was conducted to increase the response rate but the researcher was unable to do so, inspite of all the devoted effort. Therefore, this response rate was seen as an acceptable response rate as it represents 161 textile manufacturers.

\section{Statistical Analysis and Discussion}

To investigate, generally, whether marketing managers in Jordan play an important role in their companies' strategic market planning, respondents were asked question number one of the questionnaire. Table 1 reveals the results.

Table (1)

Respondents' opinions regarding their role in the marketing management process

\begin{tabular}{|c|c|c|}
\hline Response & $\mathrm{n}$ & $\%$ \\
\hline Yes & 93 & 58 \\
\hline No & 68 & 42 \\
\hline
\end{tabular}

It is obvious that the majority (i.e., 58\%) of the surveyed marketing managers indicated that they were given an important role in their companies' marketing management process. To further investigate their role regarding this issue, respondents were asked question number 2 . This question, which included many statements related to the marketing management process, intended to examine their role in analyzing their companies' target market(s), planning, organizing, implementing and controlling their companies' marketing activities. 


\subsection{Market analysis}

Three statements, i.e., Q2a, Q2b and Q2c were used to examine the role of marketing managers in market analysis. Table 2 shows the frequencies of respondents' answers to the three statements and the mean values.

Table (2)

Respondents' answers regarding their role in market analysis

\begin{tabular}{|c|c|c|c|c|c|c|c|c|c|c|c|}
\hline \multirow[t]{2}{*}{ level of agreement } & \multicolumn{2}{|c|}{$\begin{array}{c}\text { Strongly } \\
\text { agree }\end{array}$} & \multicolumn{2}{|c|}{ Agree } & \multicolumn{2}{|c|}{ Uncertain } & \multicolumn{2}{|c|}{$\begin{array}{c}\text { Quite } \\
\text { disagree }\end{array}$} & \multicolumn{2}{|c|}{$\begin{array}{l}\text { Strongly } \\
\text { disagree }\end{array}$} & \multirow[t]{2}{*}{$\begin{array}{l}\text { Mean } \\
\text { Value } \\
\end{array}$} \\
\hline & $\mathrm{n}$ & $\%$ & $\mathrm{n}$ & $\%$ & $\mathrm{n}$ & $\%$ & $\mathrm{n}$ & $\%$ & $\mathrm{n}$ & $\%$ & \\
\hline $\begin{array}{l}\text { Q2a- I have an important role to play in } \\
\text { monitoring and analyzing my company's micro } \\
\text { and macro marketing environments. }\end{array}$ & 41 & 25.4 & 44 & 27.3 & 17 & 10.6 & 28 & 17.4 & 31 & 19.3 & 3.22 \\
\hline $\begin{array}{l}\text { Q2b- I have an important role to play in } \\
\text { analyzing and identifying the short, medium } \\
\text { and long-run marketing opportunities in the } \\
\text { company's target market. }\end{array}$ & 39 & 24.2 & 46 & 28.6 & 19 & 11.8 & 27 & 16.8 & 30 & 18.6 & 3.23 \\
\hline $\begin{array}{l}\text { Q2c- My company gives me an important role } \\
\text { in setting the marketing objectives that should } \\
\text { be consistent with the firm's general goals. }\end{array}$ & 43 & 26.7 & 45 & 28.0 & 21 & 13.0 & 31 & 19.3 & 21 & 13.0 & 3.36 \\
\hline
\end{tabular}

It is evident from Table 2 that, only a small majority have indicated that they have an important role to play in market analysis with mean values of $3.22,3.23$ and 3.36 consecutively. To examine if there was a significant difference between marketing managers who say that they played an important role in the marketing management process and those who did not, regarding market analysis, a T-test was employed. This was done after a reliability test was carried out between the statements Q2a, Q2b, and Q2c. The results of the analysis suggested the use of the three statements combined together. Table 3 shows the statistical results.

Table (3)

The role of the marketing manager in market analysis

\begin{tabular}{|c|c|c|c|c|c|c|c|}
\hline Issue & Role & $\mathrm{n}$ & $\mathrm{N}$ & T-value & $\mathrm{dF}$ & Chronbach Alpha & level of significance \\
\hline $\begin{array}{l}\text { Market } \\
\text { analysis }\end{array}$ & $\mathrm{S}$ & 68 & 161 & 1.156 & 159 & 0.69 & - \\
\hline
\end{tabular}

As it can be seen from Table 3, no significant difference was found between the two groups of marketing managers regarding their role in market analysis. The insignificance could be related to two things: First, marketing managers do not really know what market analysis is all about, which the researcher was able to detect during interviewing them and before delivering the questionnaires. A large majority of them did not know the marketing concept which, of course, would tell a lot about their marketing background. Second, marketing managers did not tell the truth about the duties of their jobs and they wanted to be perceived as important decision makers and, hence, to be seen as prestigious as the titles of their jobs. 


\subsection{Planning}

Five statements, i.e., $\mathrm{Q}_{2} \mathrm{~d}, \mathrm{Q}_{2} \mathrm{e}, \mathrm{Q}_{2} \mathrm{f}, \mathrm{Q}_{2} \mathrm{~g}$ and $\mathrm{Q} 2 \mathrm{~h}$ were designed to examine the role of marketing managers in planning the marketing activities. Table 4 reveals the frequencies of respondents' answers to these statements and the mean values.

Table (4)

Respondents' answers regarding their role in planning the marketing activities

\begin{tabular}{|c|c|c|c|c|c|c|c|c|c|c|c|}
\hline \multirow[b]{2}{*}{ Statement } & \multicolumn{2}{|c|}{$\begin{array}{c}\text { Strongly } \\
\text { agree }\end{array}$} & \multicolumn{2}{|c|}{ Agree } & \multicolumn{2}{|c|}{ Uncertain } & \multicolumn{2}{|c|}{$\begin{array}{c}\text { Quite } \\
\text { disagree }\end{array}$} & \multicolumn{2}{|c|}{$\begin{array}{l}\text { Strongly } \\
\text { disagree }\end{array}$} & \multirow[t]{2}{*}{\begin{tabular}{|l|} 
Mean \\
Value \\
\end{tabular}} \\
\hline & $\mathrm{n}$ & $\%$ & $\mathrm{n}$ & $\%$ & $\mathrm{n}$ & $\%$ & $\mathrm{n}$ & $\%$ & $\mathrm{n}$ & $\%$ & \\
\hline $\begin{array}{l}\text { Q2d- I play an important role in planning } \\
\text { the marketing mix strategy and other } \\
\text { marketing activities. }\end{array}$ & 41 & 25.5 & 49 & 30.4 & 24 & 14.9 & 27 & 16.8 & 20 & 12.4 & 3.40 \\
\hline $\begin{array}{l}\text { Q2e- My organization gives me an } \\
\text { important role in specifying the expected } \\
\text { results so that the organization can } \\
\text { anticipate what its situation will be at the } \\
\text { end of the current planning period. }\end{array}$ & 39 & 24.2 & 50 & 31.1 & 21 & 13.0 & 29 & 18.0 & 22 & 13.7 & 3.34 \\
\hline $\begin{array}{l}\text { Q2f- I participate in identifying the } \\
\text { resources needed to carry out the planned } \\
\text { marketing activities so that a budget can } \\
\text { be developed. }\end{array}$ & 29 & 18.0 & 40 & 24.9 & 18 & 11.2 & 35 & 21.7 & 39 & 24.2 & 2.91 \\
\hline $\begin{array}{l}\text { Q2g- I participate in describing, in sufficient } \\
\text { details, the activities that are to take place so } \\
\text { that responsibilities for implementation can } \\
\text { be assigned. }\end{array}$ & 39 & 24.2 & 47 & 29.2 & 21 & 13.0 & 29 & 18.0 & 25 & 15.6 & 3.29 \\
\hline $\begin{array}{l}\text { Q2h- I participate in providing what is } \\
\text { required for the monitoring of the marketing } \\
\text { activities and the results so that control can } \\
\text { be exerted }\end{array}$ & 47 & 29.2 & 50 & 31.1 & 16 & 9.9 & 27 & 16.8 & 21 & 13.0 & 3.47 \\
\hline
\end{tabular}

$\mathrm{n}=$ number of valid observations

As can be seen from Table 4, a small majority of marketing managers have agreed with the provided statements except for statement $\mathrm{Q}_{2} \mathrm{f}$ with mean values of $3.40,3.34$, $2.91,3.29$ and 3.47 consecutively. Therefore, it can be said that a small majority of the surveyed marketing managers in Jordan participate, in one way or another, in the planning of their companies' marketing activities. This was not the case when it came to identifying the needed resources to carry out the planned marketing activities. It is obvious that the majority of them were either uncertain or disagreed with the statement (i.e., Q2f). $^{2}$

A T-test was carried out to examine if a significant difference exists between marketing managers who say that they played an important role in the marketing management process and those who didn't, regarding the planning of the marketing activities. This was done after reliability analysis was carried out between the five statements (i.e., $\mathrm{Q}_{2} \mathrm{~d}, \mathrm{Q}_{2} \mathrm{e}, \mathrm{Q}_{2} \mathrm{f}, \mathrm{Q}_{2} \mathrm{~g}$ and $\mathrm{Q}_{2} \mathrm{~h}$ ) and the results suggested the use of the five statements combined together. Table 5 shows the results.

As Table 5 shows, no significant difference was found between the two groups of marketing managers regarding their role in planning the marketing activities. The explanation of this finding may be related to the fact that these firms are still 
production-oriented and, therefore, the importance of the marketing unit is not fully recognized.

Table (5)

The Role of the marketing manager in planning the marketing activities

\begin{tabular}{|c|c|c|c|c|c|c|c|}
\hline Issue & Role & $\mathrm{n}$ & $\mathrm{N}$ & $\mathrm{T}$-value & $\mathrm{dF}$ & $\begin{array}{c}\text { Chronbach } \\
\text { Alpha }\end{array}$ & $\begin{array}{c}\text { level of } \\
\text { significance }\end{array}$ \\
\hline $\begin{array}{c}\text { Planning the marketing } \\
\text { activities }\end{array}$ & $\mathrm{S}$ & 68 & 161 & 1.133 & 159 & .78 & - \\
\hline
\end{tabular}

$\mathrm{n}=$ number of valid observations

$\mathrm{N}=$ Number of cases included in the test

$\mathrm{S}=$ small role

- = No significant difference was found

\subsection{Organizing}

Examining the role of marketing managers in organizing the marketing activities was done through the use of $\mathrm{Q}_{2} \mathrm{i}, \mathrm{Q}_{2} \mathrm{j}$, and $\mathrm{Q}_{2} \mathrm{k}$. Table 6 shows the frequencies of respondents answers to the three statements and the mean values.

Table (6)

Respondents' answers to the statements used to examine their role in organizing the marketing activities

\begin{tabular}{|c|c|c|c|c|c|c|c|c|c|c|c|}
\hline \multirow[b]{2}{*}{ Statement } & \multicolumn{2}{|c|}{$\begin{array}{c}\text { Strongly } \\
\text { agree }\end{array}$} & \multicolumn{2}{|c|}{ Agree } & \multicolumn{2}{|c|}{ Uncertain } & \multicolumn{2}{|c|}{$\begin{array}{c}\text { Quite } \\
\text { disagree }\end{array}$} & \multicolumn{2}{|c|}{$\begin{array}{l}\text { Strongly } \\
\text { disagree }\end{array}$} & \multirow[t]{2}{*}{\begin{tabular}{|l} 
Mean \\
Value \\
\end{tabular}} \\
\hline & $\mathrm{n}$ & $\%$ & $\mathrm{n}$ & $\%$ & $\mathrm{Sn}$ & $\%$ & $\mathrm{n}$ & $\%$ & $\mathrm{n}$ & $\%$ & \\
\hline $\begin{array}{l}\text { Q2i- Because of the dynamic marketing } \\
\text { environment, the place of the marketing unit in my } \\
\text { company has been elevated and, therefore, my } \\
\text { company promotes close coordination with other } \\
\text { functional areas such as, production, finance, and } \\
\text { personnel. }\end{array}$ & 45 & 28.0 & 46 & 28.6 & 23 & 14.2 & 27 & 16.8 & 20 & 12.4 & 3.43 \\
\hline $\begin{array}{l}\mathrm{Q}_{2} \mathrm{j}-\text { Therefore, my company allows me to divide } \\
\text { the work into specific activities and delegate } \\
\text { responsibilities and authorities for those activities } \\
\text { to persons in various positions within the marketing } \\
\text { unit. }\end{array}$ & 42 & 26.1 & 48 & 29.9 & 18 & 11.2 & 23 & 14.2 & 30 & 18.6 & 3.30 \\
\hline $\begin{array}{l}\mathrm{Q}_{2} \mathrm{k}-\mathrm{I} \text { help my company in choosing the best } \\
\text { approach for organizing its marketing activities. I } \\
\text { suggest which approach (e.g., organizing by } \\
\text { functions, by products, by regions, etc.) to be used } \\
\text { based on the number and diversity of the firms' } \\
\text { products, the characteristics and needs of the people } \\
\text { in the target market, and many other factors. }\end{array}$ & 39 & 24.2 & 51 & 31.7 & 22 & 13.7 & 20 & 12.4 & 29 & 18.0 & 3.32 \\
\hline
\end{tabular}
$\mathrm{n}=$ number of valid observations.

As it is evident from Table 6, a small majority agreed with the statements provided and, therefore, it can be assumed that a small number of marketing managers in Jordan have an important role to play in organizing their companies' marketing activities with mean values of $3.43,3.30$ and 3.32 consecutively.

To further investigate this issue, a T-test was used. The use of this test was to find if a significant difference exists between marketing managers who say that they played an important role in the marketing management process and those who didn't, in organizing their companies' marketing activities. This was done after reliability 
analysis was carried out and the results suggested the use of the three statements (i.e., Q2i, Q2j and Q2k) combined together. Table 7 shows the results.

Table (7)

The role of the marketing manager in organizing the marketing activities

\begin{tabular}{|l|c|c|c|c|c|c|c|}
\hline \multicolumn{1}{|c|}{ Issue } & Role & $\mathrm{n}$ & $\mathrm{N}$ & $\mathrm{T}$-value & $\mathrm{dF}$ & $\begin{array}{c}\text { Chronbach } \\
\text { Alpha }\end{array}$ & $\begin{array}{c}\text { level of } \\
\text { significance }\end{array}$ \\
\hline Organizing the marketing activities. & $\mathrm{S}$ & 68 & 161 & 1.173 & 159 & .81 & - \\
\hline $\mathrm{n}=$ number of valid observations \\
$\mathrm{N}=$ Number of cases included in the test \\
$\mathrm{S}=$ small role \\
- = No significant difference was found
\end{tabular}

It is clear from Table 7 that, no significant difference was found between the two groups of marketing managers, regarding their role in organizing the marketing activities. Therefore, those managers have, if any, little role to play in this issue. Probably, the production-orientation of these firms may be the cause for this finding. Marketing in developing countries is, usually, left aside and lots of emphasis are put on production.

\subsection{Implementation}

For the purpose of examining this function of the marketing management process, respondents were given five statements (i.e., Q2 $1, \mathrm{Q}_{2} \mathrm{~m}, \mathrm{Q}_{2} \mathrm{n}, \mathrm{Q}_{2} \mathrm{o}$ and $\mathrm{Q}_{2} \mathrm{p}$ ). Table 8 reveals the frequencies of respondents' answers to these statements and the mean values.

The findings reported in Table 8 suggest that, a larger majority than what was reported in pervious Tables, have agreed with the given statements. Therefore, it can be concluded that, the role of those managers in Jordan may be enhanced when it comes to implementing the marketing activities with mean values of $3.75,3.50,3.61$, 3.50 and 3.47 consecutively. To investigate if a significant difference exists between those who say that they played an important role in the marketing management process and those who didn't, regarding their role in implementing the marketing activities, a T-test was used. This test was employed after reliability analysis was carried out between the five statements (i.e., Q21, Q2m, Q2n, Q20 and Q2p) and the results suggested the use of the five statements combined together. Table 9 shows the results.

As can be seen from Table 9, Marketing managers who say that they had an important role to play in the marketing management process have had a significantly higher role to play in the implementation of the marketing activities than those who didn't, at the 0.10 level. This relatively weak significance could mean that those marketing managers are more likely to be sales managers than marketing managers. Marketing managers practice all marketing management functions, but the findings showed, so far, that the role of those managers came into existence when the implementation of the marketing plan took place. This finding is real and logical since most of previous research on firms of developing countries concluded that these firms are production-oriented rather than marketing-oriented. 
Table (8)

Respondents' answers to the statements used in examining the implementation of the marketing activities

\begin{tabular}{|c|c|c|c|c|c|c|c|c|c|c|c|}
\hline \multirow[t]{2}{*}{ agreement } & \multicolumn{2}{|c|}{$\begin{array}{c}\text { Strongly } \\
\text { agree }\end{array}$} & \multicolumn{2}{|c|}{ Agree } & \multicolumn{2}{|c|}{ Uncertain } & \multicolumn{2}{|c|}{$\begin{array}{c}\text { Quite } \\
\text { disagree }\end{array}$} & \multicolumn{2}{|c|}{$\begin{array}{l}\text { Strongly } \\
\text { disagree }\end{array}$} & \multirow[t]{2}{*}{$\begin{array}{l}\text { Mean } \\
\text { Value }\end{array}$} \\
\hline & $\mathrm{n}$ & $\%$ & $\mathrm{n}$ & $\%$ & $\mathrm{n}$ & $\%$ & $\mathrm{n}$ & $\%$ & $\mathrm{n}$ & $\%$ & \\
\hline $\begin{array}{l}\mathrm{Q}_{2} \text { 1- My company allows me to coordinate } \\
\text { the activities of marketing personnel within } \\
\text { the firm to achieve marketing objectives. }\end{array}$ & 57 & 35.4 & 49 & 30.4 & 25 & 15.6 & 17 & 10.6 & 13 & 8.0 & 3.75 \\
\hline $\begin{array}{l}\mathrm{Q}_{2} \mathrm{~m} \text { - It is my role to facilitate coordination } \\
\text { by making all individuals aware of how their } \\
\text { jobs are related to others' jobs and how each } \\
\text { person's actions contribute to the achievement } \\
\text { of the marketing plan. }\end{array}$ & 48 & 29.9 & 47 & 29.2 & 23 & 14.2 & 23 & 14.2 & 20 & 12.5 & 3.50 \\
\hline $\begin{array}{l}\mathrm{Q}_{2} \mathrm{n}-\mathrm{It} \text { is my job to keep the rest of my } \\
\text { organization apprised of the marketing } \\
\text { group's activities. }\end{array}$ & 50 & 31.1 & 51 & 31.7 & 20 & 12.4 & 27 & 16.8 & 13 & 8.0 & 3.61 \\
\hline $\begin{array}{l}\mathrm{Q}_{2} \mathrm{O}-\mathrm{My} \text { company relies on me in } \\
\text { motivating the marketing personnel, before, } \\
\text { during and after the implementation of the } \\
\text { marketing activities. }\end{array}$ & 49 & 30.4 & 50 & 31.1 & 18 & 11.2 & 20 & 12.4 & 24 & 14.9 & 3.50 \\
\hline $\begin{array}{l}\mathrm{Q}_{2 \mathrm{p}} \text { - To secure proper implementation of the } \\
\text { marketing plan, my company provides me } \\
\text { with a good acommunication system to } \\
\text { communicate with high-level management } \\
\text { and with marketing personnel at the } \\
\text { operational level. }\end{array}$ & 47 & 29.2 & 53 & 32.9 & 15 & 9.3 & 21 & 13.0 & 25 & 15.6 & 3.47 \\
\hline
\end{tabular}

$\mathrm{n}=$ number of valid observations

Table (9)

The role of the marketing manager in implementing the marketing activities

\begin{tabular}{|l|c|c|c|c|c|c|c|}
\hline & Role & $\mathrm{n}$ & $\mathrm{N}$ & $\mathrm{T}$-value & $\mathrm{dF}$ & $\begin{array}{c}\text { Chronbach } \\
\text { Alpha }\end{array}$ & $\begin{array}{c}\text { level of } \\
\text { significance }\end{array}$ \\
\hline Implementing the marketing activities & $\mathrm{H}$ & 93 & 161 & 1.738 & 159 & .81 & $*$ \\
\hline $\mathrm{n}=$ number of valid observations \\
$\mathrm{N}=$ Number of cases included in the test \\
$\mathrm{H}=$ high role \\
$*=$ Significant at the 0.10 level
\end{tabular}

\subsection{Controlling}

Examining this function of the marketing management process is done through the use of Q2q, Q2r, and Q2s. Table 10 shows the frequencies of repondents' answers to the three statements and the mean values.

It can be seen from Table 10 that a small majority of marketing managers have agreed with the statements with mean values of $3.34,3.36$ and 3.27 consecutively, which means that those managers have some kind of responsibility in controlling the marketing activities. To further examine this responsibility, a T-test was used. This was done after reliability analysis was carried out between the three statements (i.e., Q2q, Q2r, and Q2s) and the results suggested the use of the three statements combined together. Table 11 reveals the results. 
Table (10)

Respondents' answers to the statements used to investigate their role in controlling the marketing activities

\begin{tabular}{|c|c|c|c|c|c|c|c|c|c|c|c|}
\hline \multirow{2}{*}{$\begin{array}{ll}\text { Statement } & \text { level of agreement } \\
\end{array}$} & \multicolumn{2}{|c|}{$\begin{array}{c}\text { Strongly } \\
\text { agree }\end{array}$} & \multicolumn{2}{|c|}{ Agree } & \multicolumn{2}{|c|}{ Uncertain } & \multicolumn{2}{|c|}{$\begin{array}{c}\text { Quite } \\
\text { disagree }\end{array}$} & \multicolumn{2}{|c|}{$\begin{array}{l}\text { Strongly } \\
\text { disagree }\end{array}$} & \multirow[t]{2}{*}{$\begin{array}{l}\text { Mean } \\
\text { Value }\end{array}$} \\
\hline & $\mathrm{n}$ & $\%$ & $\mathrm{n}$ & $\%$ & $\mathrm{n}$ & $\%$ & $\mathrm{n}$ & $\%$ & $\mathrm{n}$ & $\%$ & \\
\hline $\begin{array}{l}\text { Q2q-In controlling the marketing activities, } \\
\text { my company gives me an important role in } \\
\text { establishing performance standards. }\end{array}$ & 41 & 25.5 & 46 & 28.6 & 24 & 14.9 & 26 & 16.1 & 24 & 14.9 & 3.34 \\
\hline $\begin{array}{l}\text { Q2r-An important role is given to me in } \\
\text { evaluating actual performance of the } \\
\text { marketing plan and determining } \\
\text { discrepancies. }\end{array}$ & 38 & 23.5 & 50 & 31.1 & 27 & 16.8 & 24 & 14.9 & 22 & 13.7 & 3.36 \\
\hline $\begin{array}{l}\text { Q2s-My company gives me an important role } \\
\text { in taking corrective action to improve actual } \\
\text { performance of the marketing plan. }\end{array}$ & 39 & 24.2 & 47 & 29.2 & 25 & 15.6 & 19 & 11.7 & 31 & 19.3 & 3.27 \\
\hline
\end{tabular}

Table (11)

The role of the marketing manager in controlling the marketing activities.

\begin{tabular}{|c|c|c|c|c|c|c|c|}
\hline Issue & Role & $\mathrm{n}$ & $\mathrm{N}$ & $\mathrm{T}$-value & $\mathrm{dF}$ & $\begin{array}{c}\text { Chronbach } \\
\text { Alpha }\end{array}$ & $\begin{array}{c}\text { level of } \\
\text { significance }\end{array}$ \\
\hline Controlling the marketing activities & $\mathrm{S}$ & 68 & 161 & 1.732 & 159 & .74 & * \\
\hline
\end{tabular}

Table 11 shows a relatively weak significant difference exists between marketing managers who say that they played an important role in the marketing management process and those who didn't, regarding their role in controlling the implemented marketing activities at the 0.10 level. This weak significant difference could be explained through the fact that those marketing managers are responsible to their superiors (high-level management). Therefore, those managers, usually, report to their top management on issues like sales volume and sales personnel. This reporting might have been perceived by them as an important role in controlling the marketing activities, which is not of course. The answer to their claim is simple, how could their companies depend on them in something they, the marketing managers, did not analyze, plan or organize.

It could be concluded that the role of those managers in the marketing management process is weak and, therefore, the study hypothesis (i. e., H1) was supported. This is a reasonable conclusion, especially, when one remembers that most, if not all, companies of developing countries adopt the production concept rather than the marketing concept. Based on the study findings, it could be said that those managers are only "sales managers" responsible for "sales activities" and they don't have a real role to play in the functions of the "marketing management process". Taking the definition of a "marketing manager" into consideration, those managers could not be considered as marketing managers. 


\section{Conclusions and Recommendations}

Almost all writers included different marketing positions under the name of a "marketing manager", they linked the classification of those managers as "marketing managers" to the involvement in analysing, planning, implementing, and controlling the marketing activities (Kostecki, M., 1994). Hence, job title, in itself, may not necessarily correspond to the real position of a "marketing manager" and, therefore, performing the functions of the marketing management process is the real tattoo for a marketing manager. The findings of this study showed that the surveyed marketing managers have a very weak involvement in the functions of the marketing management. Thus, those mangers are no more than sales persons performing certain "sales tasks". Their jobs may be limited, because most, if not all, of these organizations adopt the production concept rather than the marketing concept and, therefore, production managers are given the upper hand in strategic market planning.

The marketing concept, as an essential business philosophy, and the role of the marketing manager must be appreciated. Although Jordanian textile manufacturers may have obstacles in adopting the marketing concept (e.g., financial, technological, etc.), they need to reconsider their position with regard to this issue. The changing political, economic, social and cultural climates in the Middle-East may prove the need for this reconsideration.

Jordanians perceive various locally made products and services as inferior to their imported counterparts. Therefore, giving those marketing managers the real role that they should perform in the functions of the marketing management may help in changing the perception that Jordanians have of locally-made products. This is important as those managers may help Jordanian textile manufacturers, and others, to become marketing-oriented and, hence, improve their competitiveness locally and internationally.

Finding and recruiting good marketing managers is an immense task, but when they are found they could be of great value to their organizations. Marketing managers can provide a guiding philosophy to better serve the needs of important consumer groups. They, also, provide inputs to strategic planners by helping in identifying attractive market opportunities and in assessing their firms' potential. Marketing managers should have an important role to play in achieving the overall objectives of their organizations. For example, marketing managers help in assessing their organizations' potential, but once their organizations' overall objectives are established, marketing managers' task will be to carry it out profitably.

Although every care is taken to robust this study, the findings reported here may not be taken for granted. Further research is needed to support the validation and generalizability of the study findings.

\section{References}

Aaker, D. (1988) Strategic Market Management, 2nd Edition, John Wiley, New York.

Ajay, K. and Bernard, J. (1990) "Market Orientation: the Construct, Research Propositions and Managerial Implications", Journal of Marketing, 54, No.2, pp.1-18. 
Bearden W., Ingram T., and Lafroge R. (1995) Marketing: Principles and Perspectives, 1st Edition, Richard Irwin, USA.

Cook, V. J. Jr. (1983) "Marketing Strategy and Differential Advantage", Journal of Marketing, 47, No.2, pp. 68-75.

DeBruicker, S. and Summe, G. (1985) "Make Sure Your Customers Keep Coming Back", Harvard Business Review, 1, pp. 92-98.

Ferrel, O.; Goerge H. and David J. (1994) Strategic Marketing Management: Text and Cases, Cincinnati: South-Western.

George, S. D. (1994) "The Capabilities of Market-Driven Organizations", Journal of Marketing, 58, No.4, pp. 37-52.

Guiltinan, J. and Paul, G. (1991) Marketing Management Strategies and Programs, Fourth Edition, McGraw-Hill, USA.

King, N. (1985) "The Marketing Audit: An Extension of the Marketing Control Process", Managerial Finance (UK), 4, pp. 23-26.

Kostecki M. (1994) Marketing Strategies for Services, 1st Edition, J \& L, Ltd, Filey, North Yorkshire, UK.

Kotler P. (1994) Marketing Management: Analysis, Planning, Implementation and Control, 6th Ed. Englewood Cliffs, N, J. : Prentice-Hall.

Kotler, P. and Armstrong G. (1994) Principles of Marketing, Sixth Edition, Prentice Hall, Englewood Cliffs, New Jersey.

Nunnally, J. (1978) Psychometric Theory, Second Edition, McGraw-Hill Book company: New York.

Peter, P. and Donnelly, J. (1995) Marketing Management: Knowledge and Skills, 4th Edition, Irwin, Inc., USA.

Peter, P. and Donnelly, J. (1991) A Preface to Marketing Management, Fifth Edition, Richard D. Irwin, Inc., USA.

Pride, W. and Ferrell, O. (1989) Marketing, Concepts and Strategies, Sixth edition, Houghton Mifflin Company: USA, p. 644.

Ravi, A. (1991) "Evolution of the Marketing Organization: New Forms For Turbulent Environments", Journal of Marketing, 55, No. 4, pp. 77-93.

Robert, J. (1995) "How Do You Know When the Price Is Right?", Harvard Business Review, 9, p.174.

Robert, W. (1986) Industrial Marketing Management, 3rd Ed., Boston: Kent.

Statistical Yearbook, Department of Statistics, The Hashemite Kingdome of Jordan, No. 46, October 1996, P.125.

Weinstein, A. (1987) Market Segmentation, Illinois: Probus Publishing Company.

Yoram, W. and Robertson, T. (1983) "Marketing Strategy: New Directions for Theory and Research", Journal of Marketing, 47, No.2, pp. 12-25. 


\section{Appendix}

\section{Questionnaire}

Q1- As a marketing manager, do you have an important role to play in your company's main marketing management functions (i.e., planning, organizing, implementing and controlling the marketing activities).

$$
\text { Yes. }
$$

No.......

Q2- To what extent would you agree or disagree with the following statements?

\begin{tabular}{|c|c|c|c|c|c|}
\hline Statement & $\begin{array}{c}\text { Strongly } \\
\text { agree }\end{array}$ & Agree & Uncertain & $\begin{array}{c}\text { Quite } \\
\text { disagree }\end{array}$ & $\begin{array}{l}\text { Strongly } \\
\text { disagree }\end{array}$ \\
\hline \multicolumn{6}{|l|}{ Market analysis } \\
\hline \multicolumn{6}{|l|}{$\begin{array}{l}\text { a- I have an important role to play in monitoring and } \\
\text { analyzing my company's micro and macro marketing } \\
\text { environments. }\end{array}$} \\
\hline \multicolumn{6}{|l|}{$\begin{array}{l}\text { b- I have an important role to play in analyzing and } \\
\text { identifying the short, medium and long-run marketing } \\
\text { opportunities in the company's target market. }\end{array}$} \\
\hline \multicolumn{6}{|l|}{$\begin{array}{l}\text { c- My company gives me an important role in setting the } \\
\text { marketing objectives that should be consistent with the } \\
\text { firm's general goals. }\end{array}$} \\
\hline \multicolumn{6}{|l|}{\begin{tabular}{|l|l|} 
Planning \\
\end{tabular}} \\
\hline \multicolumn{6}{|l|}{$\begin{array}{l}\text { d- I play an important role in planning the marketing mix } \\
\text { strategy and other marketing activities. }\end{array}$} \\
\hline \multicolumn{6}{|l|}{$\begin{array}{l}\text { e- My organization gives me an important role in } \\
\text { specifying the expected results so that the organization can } \\
\text { anticipate what its situation will be at the end of the } \\
\text { current planning period. }\end{array}$} \\
\hline \multicolumn{6}{|l|}{$\begin{array}{l}\text { f- I participate in identifying the resources needed to carry } \\
\text { out the planned marketing activities so that a budget can } \\
\text { be developed. }\end{array}$} \\
\hline \multicolumn{6}{|l|}{$\begin{array}{l}\text { g- I participate in describing, in sufficient details, the } \\
\text { activities that are to take place so that responsibilities for } \\
\text { implementation can be assigned. }\end{array}$} \\
\hline \multicolumn{6}{|l|}{$\begin{array}{l}\text { h- I participate in providing, what is required for the } \\
\text { monitoring of the marketing activities and the results so } \\
\text { that control can be exerted. }\end{array}$} \\
\hline \multicolumn{6}{|l|}{ Organizing } \\
\hline \multicolumn{6}{|l|}{$\begin{array}{l}\text { i- Because of the dynamic marketing environment, the } \\
\text { place of the marketing unit in my company has been } \\
\text { elevated and, therefore, my company promotes close } \\
\text { coordination with other functional areas such as, } \\
\text { production, finance, and personnel. }\end{array}$} \\
\hline \multicolumn{6}{|l|}{$\begin{array}{l}\text { j- Therefore, my company allows me to divide the work } \\
\text { into specific activities and delegate responsibilities and } \\
\text { authorities for those activities to persons in various } \\
\text { positions within the marketing unit. }\end{array}$} \\
\hline \multirow{2}{*}{\multicolumn{6}{|c|}{$\begin{array}{l}\text { k- I help my company in choosing the best approach for } \\
\text { organizing its marketing activities. I suggest which } \\
\text { approach (e.g., organizing by functions, by products, by } \\
\text { regions, etc.) to be used based on the number and } \\
\text { diversity of the firm's products, the characteristics and } \\
\text { needs of the people in the target market, and many other } \\
\text { factors. } \\
\text { Implementing }\end{array}$}} \\
\hline & & & & & \\
\hline $\begin{array}{l}\text { 1- My company allows me to coordinate the activities of } \\
\text { the marketing personnel within the firm to achieve } \\
\text { marketing objectives. }\end{array}$ & & & & & \\
\hline
\end{tabular}




\begin{tabular}{|c|c|c|c|c|c|}
\hline Statement & $\begin{array}{l}\text { Strongly } \\
\text { agree }\end{array}$ & Agree & Uncertain & $\begin{array}{c}\text { Quite } \\
\text { disagree }\end{array}$ & $\begin{array}{l}\text { Strongly } \\
\text { disagree }\end{array}$ \\
\hline \multicolumn{6}{|l|}{$\begin{array}{l}\text { m- It is my role to facilitate coordination by making all } \\
\text { individuals aware of how their jobs are related to others' } \\
\text { jobs and how each person's actions contribute to the } \\
\text { achievement of the marketing plan. }\end{array}$} \\
\hline \multicolumn{6}{|l|}{$\begin{array}{l}\mathrm{n} \text { - It is my job to keep the rest of my organization } \\
\text { apprised of the marketing group's activities. }\end{array}$} \\
\hline \multicolumn{6}{|l|}{$\begin{array}{l}\text { o- My company relies on me in motivating the } \\
\text { marketing personnel before, during and after the } \\
\text { implementation of the marketing activities. }\end{array}$} \\
\hline \multicolumn{6}{|l|}{$\begin{array}{l}\text { p- To secure proper implementation of the marketing } \\
\text { plan, my company provides me with a good } \\
\text { communication system to communicate with high- level } \\
\text { management and with marketing personnel at the } \\
\text { operational level. }\end{array}$} \\
\hline \multicolumn{6}{|l|}{ Controlling } \\
\hline \multicolumn{6}{|l|}{$\begin{array}{l}\text { q- In controlling the marketing activities, my company } \\
\text { gives me an important role in establishing performance } \\
\text { standards. }\end{array}$} \\
\hline \multicolumn{6}{|l|}{$\begin{array}{l}\mathrm{r}-\text { An important role is given to me in evaluating actual } \\
\text { performance of the marketing plan and in determining } \\
\text { discrepancies. }\end{array}$} \\
\hline $\begin{array}{l}\text { s- My company gives me an important role in taking } \\
\text { corrective action to improve actual performance of the } \\
\text { marketing plan. }\end{array}$ & & & & & \\
\hline
\end{tabular}




\title{
تقييم دور مدراء التسويق في إدارة النشاطات التسويقية : حالة صناعة النسيج في الأردن
}

\author{
حسين عبدالله العمري \\ أستاذ مساعد \\ قسم إدارة الأعمال والمحاسبة المانس \\ الجامعة الهاشمية - الزرقا - الأردن والهابة
}

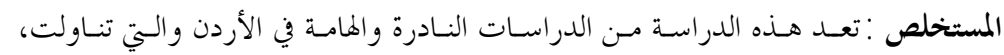

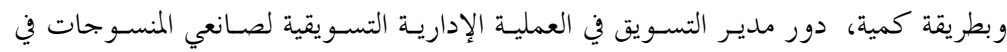

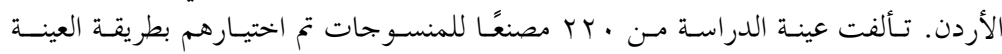

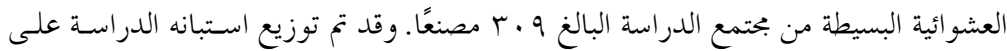

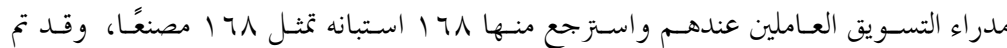

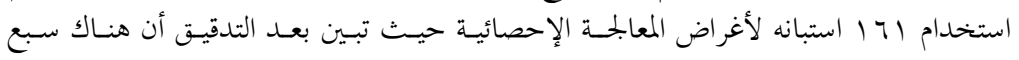
استبانات لا يمكن استخدامها وذلك لعدم الإجابة على الكثير من الأسئلة فيها.

أظهرت نتـائج هـذه الدراسـة أن مـدراء التسـويق لـدى صـانعي المنسـوجات في الأردن

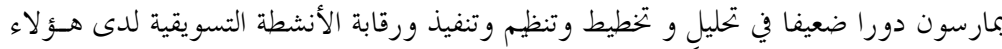

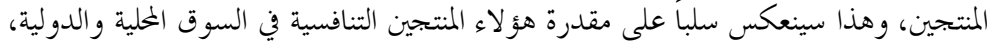

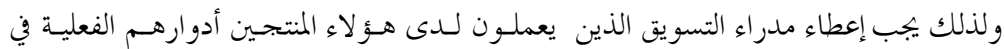

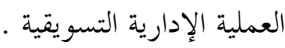

